\title{
Working
}

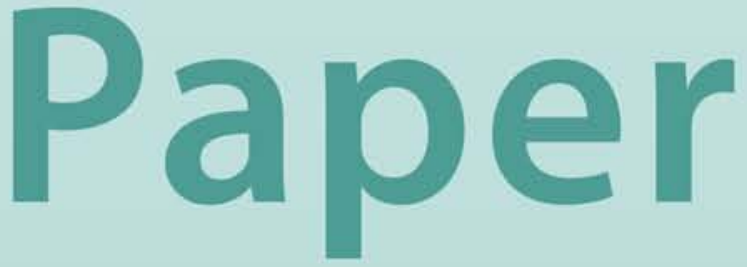




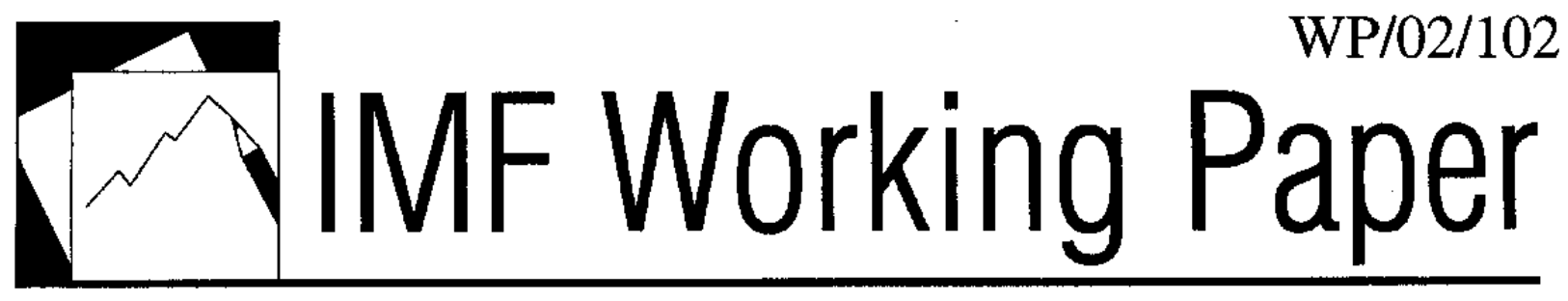

Establishing Initial Conditions in Support of Inflation Targeting

Alina Carare, Andrea Schaechter,

Mark Stone, and Mark Zelmer 


\title{
IMF Working Paper
}

Monetary and Exchange Affairs Department

\section{Establishing Initial Conditions in Support of Inflation Targeting}

Prepared by Alina Carare, Andrea Schaechter, Mark Stone, and Mark Zelmer ${ }^{1}$

Authorized for distribution by Piero Ugolini

June 2002

\begin{abstract}
The views expressed in this Working Paper are those of the author(s) and do not necessarily represent those of the IMF or IMF policy. Working Papers describe research in progress by the author(s) and are published to elicit comments and to further debate.
\end{abstract}

This paper provides some practical advice on establishing initial conditions in support of an inflation-targeting monetary framework. These conditions are divided into four areas: a mandate in support of an inflation objective and accountability for achieving this objective; macroeconomic stability; a sufficiently well-developed and stable financial system; and effective policy implementation tools. The measures taken by countries to meet these conditions are also reviewed.

JEL Classification Numbers: E52, E58, E61, E44

Keywords: monetary policy, monetary policy framework, inflation targeting, central bank

Authors' E-Mail Addresses: acarare@imf.org; aschaechter@imf.org; mstone@imf.org; mzelmer@imf.org

\footnotetext{
${ }^{1}$ The authors would like to thank Lilja Alfređdótir, Kevin Clinton, Akiva Offenbacher, Gabriel Sterne, Antti Suvanto, participants at a Monetary and Exchange Affairs Department seminar, V. Sundararajan, Warren Coats, Douglas Laxton, Alex Mourmouras, and Piero Ugolini for helpful comments and suggestions.
} 
I. Introduction

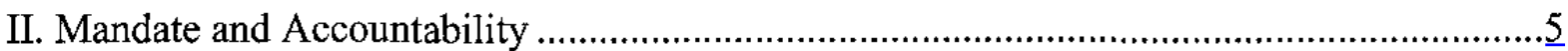

A. Mandate and Instrument Independence ..........................................................

B. Accountability and Transparency ........................................................................

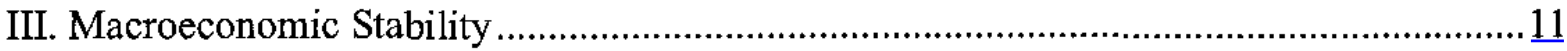

A. Absence of Fiscal Dominance........................................................................11

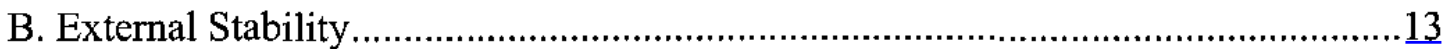

C. Level of Inflation at Adoption of Inflation Targeting ...........................................13

IV. Financial System Stability and Development............................................................14

A. Financial System Stability ………….......................................................14

B. Development of Financial Markets ..............................................................15

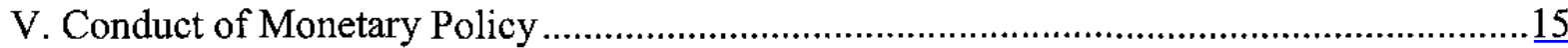

A. Monetary Operating Guide and Instruments................................................16

B. Transmission of Monetary Policy ...............................................................

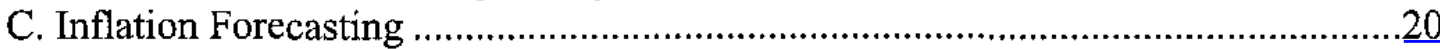

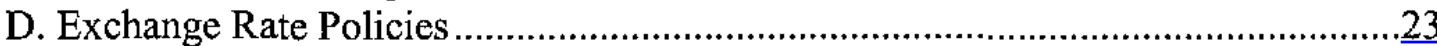

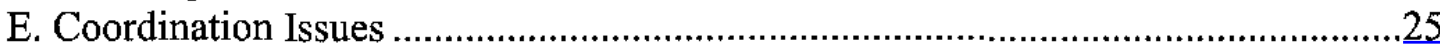

\section{Text Tables}

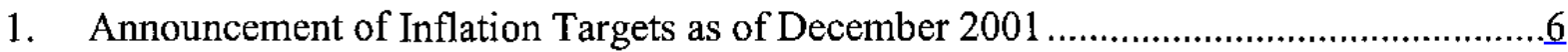

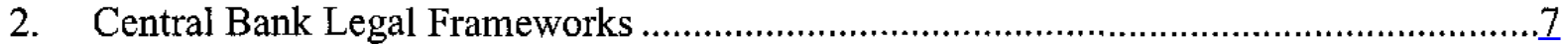

3. Communication Vehicles Employed by Inflation Targeters …...................................10

4. Operating Targets and Main Instruments of Monetary Policy ....................................17

5. Foreign Exchange Market Intervention Practices......................................................24

Box

1. Organizational Changes at Central Banks Adopting Inflation Targeting .......................22

Appendices

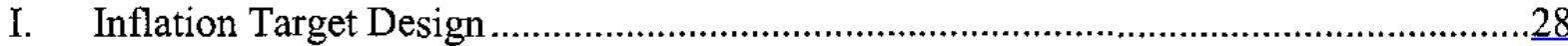

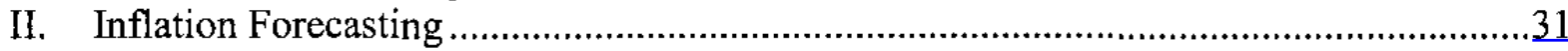

Appendix Tables

A1. Inflation Target Design: Country Experiences ...........................................................

A2. Monetary Policy Indicators in Inflation Targeting Countries.......................................34

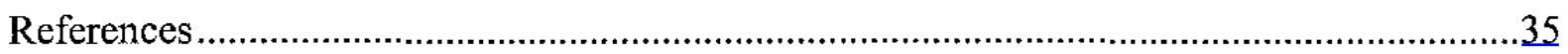




\section{INTRODUCTION}

A growing number of emerging market countries are requesting technical assistance from the Fund to help them adopt an inflation-targeting monetary framework. In recent years, the adoption of formal inflation-targeting monetary frameworks has widened from industrial countries to emerging market countries such as Brazil, Chile, Colombia, the Czech Republic, Hungary, Israel, Korea, Mexico, Poland, South Africa, and Thailand. ${ }^{2}$ Many other emerging market countries, such as the Philippines, ${ }^{3}$ Peru, and Turkey are also moving toward this framework. The challenges that industrial countries faced in adopting inflation targeting are relatively well understood, owing to their comparatively long experience in this area. Industrial countries have also benefited from well-developed financial markets and experience in using indirect, market-based instruments for implementing monetary policy. ${ }^{4}$ In contrast, the challenges confronting emerging market countries seeking to adopt inflation targeting are less well understood.

This paper addresses the initial conditions that emerging market countries can establish in support of an inflation-targeting monetary framework. Under such a framework, the inflation target prevails over any other policy objective. An inflation forecast serves as the intermediate guide, and monetary policy is conducted in a market-based, flexible, and transparent manner that fosters accountability. This paper is aimed not just at countries willing and able to adopt full-fledged inflation targeting. For those countries that have decided to float their exchange rate (at least within fairly wide bands), but are unable to adopt full-fledged inflation targeting, a preannounced inflation target, even without all the attributes of a full-fledged framework, may be preferable to a monetary aggregate anchor. The transition from a simple announcement of an inflation target to full-fledged inflation targeting may take some years. Thus, this paper addresses the key steps to be taken during the transition.

Most inflation-targeting emerging market countries will need to take the exchange rate into account in the setting of monetary policy. Of course, the credibility of an inflation-targeting framework requires that monetary policy should not aim at targeted levels of the nominal or real exchange rates. Nevertheless, monetary policy for emerging market countries may need

${ }^{2}$ Inflation targeting in emerging market countries is discussed in Schaechter, Stone and Zelmer (2000), Blejer and others (2000), Masson, Savastano and Sharma (1997), and Mishkin and Schmidt-Hebbel (2001).

${ }^{3}$ The Central Bank of Philippines announced in December 2001 that starting with 2002, it will implement an inflation targeting framework.

${ }^{4}$ Bernanke and others (1999) provide an overview of industrial countries' experience with inflation targeting. 
to take exchange rate movements into account because the exchange rate has an important impact on inflation due to the open nature of their economies. Further, disruptive exchange rate volatility arising from a thin foreign exchange market or temporary shocks is another reason for an emerging market country to smooth exchange rate movements.

The initial conditions in support of an inflation-targeting framework can be divided into four groups. First and foremost is a mandate to pursue an inflation objective and accountability of the central bank in meeting this objective:

- A central bank should have a de facto mandate to pursue the inflation target, and sufficient discretion and autonomy to set its monetary instruments accordingly.

- The public should be informed about the monetary policy framework and the conduct of monetary policy.

The second set of conditions regards the need to ensure that the inflation target will not be subordinated to other objectives:

- Monetary policy should not be dominated by fiscal priorities; the government should raise the bulk of its funding in financial markets, and government access to central bank credit should be strictly limited.

- The external position should be strong enough to enable monetary policy to pursue the inflation target as its primary objective.

- At the outset of full-fledged inflation targeting, inflation should be low enough to ensure a reasonable degree of monetary control.

The third set of conditions ensures that the financial system is developed and stable enough to implement the framework:

- There should be sufficient financial stability to enable monetary policy to pursue the inflation targets and not be sidetracked by concerns about the health of the financial sector.

- Financial markets should be sufficiently well developed to enable monetary policy to be implemented using market-based instruments, and to ensure that the conduct of monetary policy is not complicated by weaknesses in financial market infrastructure.

The need for proper tools to implement monetary policy in support of the inflation target is the final set of conditions:

- A central bank should be in a position to influence inflation through its policy instruments, and have a reasonable understanding of the links between the stance of policy and inflation. 
- Exchange rate objectives must be clearly subordinated to the inflation target. Therefore the central banks should endeavor to make clear that foreign exchange market interventions and changes in the policy interest rate intended to influence the exchange rate are only aimed at smoothing the effects of temporary shocks.

- Fiscal policy and public debt management activities should be coordinated in support of the inflation target.

The above list of initial conditions is not meant to constitute strict prerequisites for inflation targeting. That is, the absence of some of these conditions should not stand in the way of the adoption of inflation targeting, especially when policies are being introduced to establish them in the short and medium term. Indeed, experience has shown that despite the difficultics in meeting some of the initial conditions, inflation targeting has generally worked well. Ultimately, the decision to adopt inflation targeting must be based on a carefully weighing of the costs and benefits of this framework against the alternatives. This decision will entail a large measure of judgment. Further, some countries, such as Brazil, have found that an important advantage of adopting inflation targeting over other monetary frameworks is that it fosters public awareness and acceptance of monetary policy decisions, which can help reduce the cost of disinflation and enhance credibility. Finally, many of the initial conditions listed in this paper are important for the successful conduct of monetary policy regardless of the monetary regime.

The remainder of the paper is organized as follows. Chapters II through V discuss the four groups of initial conditions that support an inflation-targeting monetary framework. Each section concludes with some steps that countries can take to meet the conditions and provides some country examples. Inflation target design and inflation forecasting are discussed in detail in the appendices.

\section{Mandate AND AccountabiLity}

\section{A. Mandate and Instrument Independence}

A mandate to pursue an inflation target, a reasonable degree of instrument independence, and public accountability make up the first set of initial conditions for adopting inflation targeting. Other objectives, such as wage rates, the level of employment, or the exchange rate must be subordinated to the inflation objective. For countries seeking to engage in inflation targeting, the primary objective for monetary policy established by a political mandate (goal dependence) should be to pursue the inflation targets. Further, the central bank should in practice have sufficient discretion to set their monetary instruments as needed to pursue the targets (instrument independence).

The inflation targets can be set by either the government, the central bank, or jointly by both entities. Most full-fledged inflation-targeting countries formally involve the government in the setting of the inflation targets (Table 1). This strengthens the credibility of the 
inflation-targeting framework by indirectly committing the government to operate fiscal policy in a way that supports the inflation objective. Government involvement in setting the targets is particularly beneficial when the central bank does not have a clear mandate to pursue an inflation target as the primary objective of monetary policy. However, the credibility of delegated independence will be reduced if the government changes often. Central banks typically announce inflation targets in countries where a price stability mandate is clearly specified in their governing legislation as the primary objective for monetary policy. In this case, the announcement of the target by the central bank reflects the delegation by the government of the authority for setting monetary policy objectives to the central bank. Appendix I discusses how other characteristics of the inflation target design can contribute to credibility.

Table 1. Announcement of Inflation Targets as of December $2001^{5}$

\begin{tabular}{ll}
\hline \multicolumn{1}{c}{ Target Announced by } & \multicolumn{1}{c}{ Countries } \\
\hline Government & Brazil, Iceland, Israel, Norway, United Kingdom \\
Central bank & $\begin{array}{l}\text { Chile, Colombia, Finland, Mexico, Poland, Spain, Sweden, } \\
\text { Thailand }\end{array}$ \\
Jointly by government and central bank & $\begin{array}{l}\text { Australia, Canada, Czech Republic, Hungary, Korea, New Zealand, } \\
\text { South Africa }\end{array}$ \\
\hline
\end{tabular}

Source: Central bank websites.

Ideally, the central bank law in prospective inflation-targeting countries should be amended to define price stability as the primary objective of monetary policy, and explicitly grant sufficient instrument independence to the central bank, but this is not an absolute requirement. ${ }^{6}$ Emerging market countries that adopted inflation targeting generally preferred to introduce a central bank legal framework that grants the appropriate degree of central bank independence before introducing inflation targeting in the hope that a formal legal framework underpinning an inflation-targeting system would help build credibility for the system. (Table 2). This may reflect their histories of government intervention in monetary policy, higher and more variable rates of inflation, less developed financial systems, vulnerability to inflationary monetization of government debts, susceptibility to exchange rate crises, and

\footnotetext{
${ }^{5}$ All references to Finland and Spain in this paper are for the period prior to the introduction of the single European currency (euro) in January 1999.

${ }^{6}$ The primary objective for monetary policy in a central bank law is often set in rather vague terms, such as pursuance of "domestic price stability," while the setting of an explicit inflation target is set out separately, often through a publicly-announced agreement between the government and the central bank. Such an approach recognizes the fact that monetary frameworks evolve over time, and thus helps to limit the number of legislative amendments that might otherwise be required.
} 
IMF involvement. However, the introduction of such a legal framework is not a precondition for adopting inflation targeting. Most industrial countries, plus Brazil and Thailand, began inflation targeting before revising their legal frameworks. While tailoring the legal framework to support inflation targeting improves credibility, a central bank will acquire credibility mainly by "consistently matching word to deed," in the words of Alan Blinder, former Vice Chairman of the U.S. Federal Reserve Board.

\section{Table 2. Central Bank Legal Frameworks}

\begin{tabular}{|c|c|}
\hline Central Bank Legal Framework & Countries \\
\hline \multicolumn{2}{|l|}{ Objectives of monetary policy } \\
\hline $\begin{array}{l}\text { Domestic price stability as } \\
\text { primary objective }\end{array}$ & $\begin{array}{l}\text { Colombia, Czech Republic, Hungary, Iceland, Korea, Mexico, } \\
\text { New Zealand, Norway, Poland, Spain, Sweden, Thailand, } \\
\text { United Kingdom }\end{array}$ \\
\hline $\begin{array}{l}\text { Currency stability as primary } \\
\text { objective }\end{array}$ & Finland $2 /$, Norway \\
\hline $\begin{array}{l}\text { Currency stability plus other } \\
\text { objectives }\end{array}$ & Brazil, Australia, Canada, Chile, Israel, South Africa \\
\hline Instrument independence & $\begin{array}{l}\text { Australia 1/, Brazil, Canada 1/, Chile, Colombia, Czech Republic, } \\
\text { Finland, Hungary, Iceland, Israel, Korea 1/, Mexico, Poland, New } \\
\text { Zealand 1/, Norway 1/, South Africa, Spain, Sweden, Thailand 1/, } \\
\text { United Kingdom }\end{array}$ \\
\hline \multicolumn{2}{|l|}{ Financing of government deficits } \\
\hline Limited & $\begin{array}{l}\text { Canada, Colombia, Czech Republic, Korea, Mexico, Norway, South } \\
\text { Africa, Thailand }\end{array}$ \\
\hline Not allowed & Brazil, Chile, Finland, Hungary, Iceland, Israel, Poland, Spain, Sweden \\
\hline
\end{tabular}

Source: Central bank legislation and reports.

1/ Day-to-day instrument independence, with an override provision for the government.

2/ Also maintain a stable and secure monetary system and circulation of money.

\section{B. Accountability and Transparency}

Central banks that decide to adopt inflation targeting should be held accountable for the actions they take to pursue the inflation targets. Accountability is essential because policy transmission lags make it difficult for the public to monitor policy performance on an ongoing basis (Debelle, 1997). This stands in marked contrast to policy frameworks with explicit intermediate targets, such as exchange rate and monetary targeting regimes, where performance against the targets can be easily monitored on an ongoing basis. In addition, accountability helps to insulate monetary policy from outside political pressures. 
In order to ensure that the public has enough information to hold the central bank accountable, the monetary policy framework under inflation targeting must be transparent. In practice, transparency works as follows:

- The inflation target needs to be made explicit and public. The definition of the inflation target should comprise not only the numerical target values, but also the underlying price index and the time horizon in which the target is to be achieved. Some countries have predefined conditions ("escape clauses") under which target deviations would be tolerated.

- The public should have a clear understanding of the principal monetary policy operations that are executed, and the indicators that best reflect the stance of monetary policy. This suggests that excessive day-to-day fluctuations in the operating guide should be kept to a minimum, so that the signal being conveyed by the central bank can be readily discerned by the public. Because a short-term interest rate can be monitored by the public on a real time-basis and is easy to understand, it is usually a more transparent operating guide than one defined in terms of base money or a monetary conditions index. Any changes in the stance of monetary policy should be communicated immediately to the public.

- Announcements of changes in the stance of monetary policy should be accompanied by explanations of the factors that have motivated the change (or, in some cases, no change), and the expected effects on the inflation outlook. This will help the public monitor the central bank's commitment to the inflation target. In most inflation-targeting countries, inflation forecasts are a linchpin of the inflation-targeting framework, and they should be published and updated regularly. It is important that the public understands the assumptions underlying the central bank's inflation outlook and the uncertainties (risks) associated with it (Section V.C.).

- To avoid situations where the credibility of the inflation-targeting framework is undermined by target breaches, the central bank should signal any expected potential breaches ahead of time, its view on why the breach is expected to occur (e.g., increases in commodity prices which are normally beyond the control of the central bank), and the actions it is taking (and over what time frame) to bring inflation back on target.

- Public accountability also requires an ex-post assessment of the performance of monetary policy. There should be a comprehensive discussion of the behavior of inflation relative to target through a review of economic and financial developments, both at home and abroad, that have an impact on inflation and the central bank's policy response.

Establishing transparency by communicating the above information does not require sophisticated vehicles. What is important is that information be timely conveyed in a consistent fashion, and presented in a way that makes it readily understood by the target 
audience. In its simplest form, this could be achieved through regular media releases and press conferences that cover the information mentioned previously. For example, a lack of resources and expertise to produce a sophisticated inflation report should not be viewed as an impediment to successfully adopting inflation targeting, so long as the central bank conveys its assessment of the inflation outlook and its policy operations to the public through other vehicles. Indeed, the first countries to adopt inflation targeting were able to conduct monetary policy successfully before they introduced sophisticated inflation or monetary policy reports. Additional communication vehicles—such as inflation reports, publication of research, and speeches by the central bank management - can be established over time with the experience of current inflation targeters serving as guidance. Brazil, for example, followed very much the path of the United Kingdom in designing its inflation report (including the setup of its inflation forecasts) and also in deciding to publish the minutes of its Monetary Policy Committee meetings.

A central bank should allocate sufficient resources and build expertise in external relations and economic research to build transparency. Common techniques employed by inflation-targeting central banks, but increasingly also by other central banks that conduct their monetary policy in a transparent manner, are:

- Regular press releases and press conferences following meetings of central banks' monetary policy decision makers are frequently used to immediately inform the public about monetary policy decisions.

- Regular inflation reports can be used to provide detailed accounts of recent economic and financial developments, and their effects on the behavior of inflation relative to target. Typically, the reports are divided into the various supply and demand factors and indicators of inflation expectations that are thought to have an impact on inflation. They should be released on a regular basis (e.g., quarterly), and include an inflation outlook that coincides at a minimum with the transmission lag of monetary policy. The inflation projections can either be limited to qualitative discussions, with at most point-estimates of future inflation for the following 12-24 months, or comprise quantitative inflation forecasts for which the associated risks are illustrated as confidence intervals ("fan-charts").

- Common ways to present the overall inflation-targeting framework include special central bank publications (including descriptions on the central bank's web page) and outreach efforts (e.g., speeches, conferences, and the like) by central bank officials to the private sector and media. Public appearances of senior central bank officials before parliamentary committees, open letters to the parliament, and in some cases, publications of the minutes of monetary policy meetings are some other ways to enhance central bank accountability.

Table 3 provides an overview on the communication vehicles used by inflation-targeting countries. 
Table 3. Communication Vehicles Employed by Inflation Targeters

\begin{tabular}{|c|c|c|c|c|c|c|c|}
\hline \multirow[b]{2}{*}{$\begin{array}{c}\text { Inflation-Targeting } \\
\text { Countries }\end{array}$} & \multirow[b]{2}{*}{$\begin{array}{c}\text { Announce } \\
\text { Monetary } \\
\text { Actions via } \\
\text { Press Release }\end{array}$} & \multicolumn{3}{|c|}{ Inflation / Monetary Policy Reports } & \multicolumn{3}{|c|}{ Other Means of Communication } \\
\hline & & Frequency & $\begin{array}{c}\text { Review } \\
\text { Inflation } \\
\text { Performance } \\
\text { and Monetary } \\
\text { Actions }\end{array}$ & Inflation Outlook & $\begin{array}{c}\text { Publish: } \\
\text { Research/ } \\
\text { Models Used for } \\
\text { Inflation Outlook }\end{array}$ & $\begin{array}{l}\text { Media and } \\
\text { Other Public } \\
\text { Presentations }\end{array}$ & $\begin{array}{l}\text { Publication of } \\
\text { Minutes of } \\
\text { Monetary } \\
\text { Policy } \\
\text { Committee }\end{array}$ \\
\hline \multicolumn{8}{|l|}{ Emerging Markets } \\
\hline Brazil & Yes & Quarterly & Yes & $\begin{array}{c}\text { Two-year } \\
\text { fan-charts } \\
\text { with discussion }\end{array}$ & Yes/No I/ & Yes & Yes \\
\hline Chile & Yes & $\begin{array}{c}\text { Three times a } \\
\text { year }\end{array}$ & Yes & $\begin{array}{l}\text { Two-year } \\
\text { fan-charts with } \\
\text { discussion }\end{array}$ & Yes/Yes & Yes & No \\
\hline Colombia & Yes & Monthly & Yes & $\begin{array}{l}\text { Two-year } \\
\text { fan-charts with } \\
\text { discussion }\end{array}$ & Yes/Most & Yes & No \\
\hline Czech Republic & Yes & Quarterly & Yes & $\begin{array}{l}\text { One-year range } \\
\text { with discussion }\end{array}$ & Yes/No & Yes & Yes \\
\hline Hungary & Yes & Quarterly & Yes & $\begin{array}{l}\text { Two-year fan } \\
\text { charts with } \\
\text { discussion }\end{array}$ & Yes/Some & Yes & No \\
\hline Israel & Yes & Monthly & Yes & $\begin{array}{l}\text { Two year range } \\
\text { with discussion }\end{array}$ & Yes/Some & Yes & No \\
\hline Mexico & Yes & Quarterly & Yes & $\begin{array}{l}\text { Qualitative } \\
\text { discussion }\end{array}$ & $\mathrm{Yes} / \mathrm{No}$ & Yes & No \\
\hline Poland & Yes & Quarterly & Yes & $\begin{array}{l}\text { Qualitative } \\
\text { discussion }\end{array}$ & Yes/No & Yes & No $2 /$ \\
\hline Thailand & Yes & Quarterly & Yes & $\begin{array}{l}\text { Two-year fan } \\
\text { charts with } \\
\text { discussion }\end{array}$ & Yes/Yes & Yes & No \\
\hline \multicolumn{8}{|l|}{ Industrial Countries } \\
\hline Australia & Yes & Quarterly & Yes & $\begin{array}{l}\text { Two-year point } \\
\text { estimate with } \\
\text { discussion }\end{array}$ & Yes/Yes & Yes & No \\
\hline Canada & Yes & $\begin{array}{c}\text { Semi-annuaily } \\
\text { with quarterly } \\
\text { updates }\end{array}$ & Yes & $\begin{array}{l}\text { One-year point } \\
\text { estimate with } \\
\text { discussion }\end{array}$ & Yes/Yes & Yes & No \\
\hline Iceland & Yes & Quarterly & Yes & $\begin{array}{l}\text { Two-year point } \\
\text { estimates and } \\
\text { fan-charts with } \\
\text { discussion }\end{array}$ & Yes/No & Yes & No \\
\hline Kotea & Yes & Quarterly & Yes & $\begin{array}{l}\text { One-year point } \\
\text { estimate with } \\
\text { discussion }\end{array}$ & Yes/No & Yes & No \\
\hline New Zealand & Yes & Quarterly & Yes & $\begin{array}{l}\text { Two-year point } \\
\text { estimates with } \\
\text { discussion }\end{array}$ & Yes/Yes & Yes & No \\
\hline Norway & Yes & $\begin{array}{c}\text { Three times a } \\
\text { year }\end{array}$ & Yes & $\begin{array}{l}\text { Two-year point } \\
\text { fan-charts with } \\
\text { discussion }\end{array}$ & Yes/Yes & Yes & No \\
\hline Sweden & Yes & Quarterly & Yes & $\begin{array}{l}\text { Two-year point } \\
\text { fan-charts with } \\
\text { discussion }\end{array}$ & Yes/Yes & Yes & Yes \\
\hline United Kingdom & Yes & Quarterly & Yes & $\begin{array}{c}\text { Two-year } \\
\text { fan-charts with } \\
\text { discussion }\end{array}$ & Yes/Yes & Yes & Yes \\
\hline
\end{tabular}

Sources: Central bank websites.

1/There are plans to publish details of the models used in Brazil once authorities are confident that the models are reasonably stable. 2/ The National Bank of Poland does not publish the minutes of the MPC meetings but the voting outcome. 


\section{Macroeconomic Stability}

The macroeconomic instability that often motivates the shift to inflation targeting can pose risks for its credibility by potentially burdening the central bank with conflicting objectives. Adopting inflation targeting before enough time has passed from the time of the motivating crisis or period of unfavorable economic developments risks a reoccurrence of these factors, which might compel monetary policy to subordinate the new inflation objective. Output is usually implicitly incorporated in the objective function, especially as output levels may contain information about future inflation independent of current inflation. In addition, the inflation target may come into conflict with exchange rate smoothing if policy interest rate settings are excessively dominated by short-run exchange rate concerns. This may be especially true for countries with thin foreign exchange markets and a history of currency instability. Similarly, the inflation target can conflict with financial stability, particularly in the context of a weak banking system and shallow financial markets. This risk is especially important for emerging market economies because they tend to be more prone to fiscal imbalances and financial and exchange rate crises due to their more concentrated real economies and less developed financial systems (Mishkin, 2000).

\section{A. Absence of Fiscal Dominance}

Conducting monetary policy with an inflation target requires that monetary policy not be dominated by fiscal concerns. By minimizing the possibility of monetization of a large fiscal deficit, a strong fiscal position helps to reinforce the credibility of the inflation-targeting framework, and thus can limit the real costs to the economy of bringing inflation down (Masson, Savastano, and Sharma, 1997, and Mishkin, 2000). How important a strong fiscal position is at the onset of inflation targeting depends foremost on a country's past history with inflation, the government's track-record in influencing monetary policy to satisfy shortterm fiscal priorities, and the government's ability to access financial markets to meet its funding requirements. These different starting positions help to determine the extent to which institutional arrangements-such as limits on central bank financing of the government or fiscal rules-are needed to help build the credibility of the inflation-targeting framework.

In principle, two cases can be distinguished:

- The first involves countries that have a history of high inflation-often the result of direct or indirect financing of budget deficits by the central bank, or limited access to financial markets to finance government deficits. For them, a strong fiscal position is an essential precondition for establishing the credibility of an inflation-targeting framework. Given their poor inflation track records and the lack of market access to fund government deficits, the public may fear that the viability of the inflation-targeting framework could be undermined by fiscal priorities. The stock of government debt outstanding and the economy's vulnerability to shocks also play a role in determining whether an inflation-targeting framework might be undermined by fiscal priorities. 
- The second case includes countries that have enjoyed relatively low inflation and are able to access markets to meet their financial requirements. Given the government's ability to access markets to fund budget deficits and a history of relatively low inflation, the credibility of the inflation-targeting framework is less likely to be undermined by the government's fiscal situation and tax collection ability (Huang and Wei, 2001). In fact, an inflation-targeting framework may help ensure that any fiscal concerns are not compounded by uncertainty regarding the conduct of monetary policy. However, in the early days of an inflation-targeting framework, the Canadian experience suggests that fiscal uncertainty may require a central bank to accept tighter-than-desired monetary conditions to demonstrate its commitment to the inflation target (Clinton and Zelmer, 1997).

Institutional arrangements that can help contain concerns that fiscal deficits might be monetized by the central bank are: (i) instrument independence; and (ii) clear limits on the government's use of central bank financing. Limits on the use of central bank facilities, such as credit lines and positive balances, ensure that government financing needs do not raise the specter of inflationary monetary financing or interfere with the central bank's ability to manage the amount of liquidity in the financial system. Establishing both elements before an inflation-targeting framework is introduced can contribute to public confidence in the framework. Most emerging market inflation-targeting countries established these elements in their central bank legislation, reflecting the experience of high inflation induced by the monetization of fiscal deficits, the higher levels of government debt for emerging market countries relative to industrial countries, and their greater vulnerability to shocks.

A joint formulation of the inflation target by the government and the central bank, which explicitly builds on the fiscal outlook, can also help avoid conflicts between monetary and fiscal policy. In cases where fiscal deficits are large and inflation is above the long-term target rate, this may result in a target that is less ambitious than those where monetary policy does not have to accommodate fiscal priorities. While such a policy may dampen the costs of disinflation, it may also lengthen the disinflation path. There is a risk of losing credibility when the balance tilts too far in favor of fiscal considerations.

In practice, the fiscal position of emerging market countries should generally be strengthened ahead of their transition to inflation-targeting, whereas those of industrial countries often have improved after they adopted inflation targeting. Some of the emerging market inflation-targeting countries, such as Israel, Mexico, Poland, and South Africa, have embarked on a path of strengthening their fiscal position before adopting an inflation-targeting framework, or at least at the beginning of the process. More broadly, net government debt to GDP declined prior to the beginning of the transition to inflation targeting for most emerging market countries (Schaechter, Stone, and Zelmer, 2000). In contrast, government debt rose prior to inflation targeting in industrial countries, and structural fiscal balances generally worsened. This discrepancy may reflect the need for emerging market countries to send a stronger signal that their new inflation-targeting frameworks will not be undermined by weak fiscal positions, especially as emerging market countries often have higher levels of government debt. 


\section{B. External Stability}

A country's external position should show sufficient stability to enable monetary policy to focus on pursuing the inflation target over time without being sidetracked for prolonged periods of time by developments in the foreign exchange market. While a country's external position has not been a factor in determining the appropriate timing for adopting inflation targeting (Schaechter, Stone, and Zelmer, 2000), the adoption of inflation targeting by most emerging market countries typically followed several years of external stability. An exception is Brazil, which weathered pressures on its currency with international support just prior to introducing inflation targeting. The European industrial countries adopted inflation targeting shortly after exiting the Exchange Rate Mechanism because they needed to find a substitute nominal anchor, and New Zealand and Canada had paved the way for that logical alternative.

Policy measures are available to reduce potential conflicts between an inflation target and external instability. First and foremost, the prudential supervision and monitoring of bank and nonbank financial institutions should be maintained at high standards so that the stability of the financial system is not compromised by exchange rate movements. Measures should also be taken to deepen and broaden financial markets. In particular, a deep and well-functioning foreign exchange market can help reduce the risk that pursuance of the inflation target might be compromised by the central bank having to adjust its monetary stance for prolonged periods of time to contain turbulence in that market.

\section{Level of Inflation at Adoption of Inflation Targeting}

At the outset of full-fledged inflation targeting, inflation should be low enough to ensure a reasonable degree of monetary control. Most industrial countries adopted a full-fledged inflation-targeting framework at a time when inflation was declining. Countries that started with higher rates of inflation and crawling exchange rate regimes disinflated over long transition periods to limit disruptions to the real economy. Chile, Israel, and Poland slowly shifted from a crawling exchange rate regime to an inflation-targeting framework. The success of the disinflation efforts of Chile and Israel are instructive. Their initial rates of inflation were moderate - less than 25 percent. Moreover, disinflation was made easier by lasting improvements in structural and fiscal policies. Both countries distinguished between the long-run inflation goal and interim inflation targets. Inflation targeting frameworks have yet to be used to engineer major disinflation from a starting point of high inflation, although the current efforts to introduce inflation targeting in Turkey should prove to be an interesting test case.

Responses to breaches of inflation targets largely depend on whether or not inflation is at or above the long-run target. When the inflation target is at the long-run rate policy, responses to breaches of the floor and ceiling of the target range tend to be symmetric in order to limit output variability. Countries that are disinflating, in contrast, accept below-target inflation outcomes, and have taken advantage of unexpected disinflationary outcomes to announce 
lower targets. Transparency and preemptive policy responses seem to have limited the damage to credibility from target ceiling breaches.

\section{Financial System Stability ANd DEVElopMENT}

\section{A. Financial System Stability}

Financial stability enables monetary policy to pursue the inflation targets and not be sidetracked by concerns about the health of the financial sector. Financial stability is defined here as a financial system which markets view as having a minimal vulnerability to crisis, as manifested, for example, in low risk premia. Financial system stability bolsters the credibility of monetary policy, thereby helping to anchor inflation expectations to the inflation target. Financial stability is a greater concern for emerging market country central banks embarking on establishing an inflation-targeting framework because they are more vulnerable to financial crises.

Two potential concerns for an inflation-targeting central bank are raised by financial stability. First, large bailouts of financial institutions through the provision of central bank liquidity could raise concerns that the central bank might not be able to fully sterilize the monetary impact, and thus could generate inflation pressures. Second, the central bank's ability to pursue the inflation target could be constrained if an increase in interest rates needed to tighten monetary conditions threatens the health of systemically important financial institutions or markets owing to highly leveraged or exposed balance sheets.

Financial system stability has preceded the adoption of inflation targeting by emerging market countries, but not for all industrial countries. Finland, New Zealand, and Sweden experienced financial sector crises a few years prior to the introduction of inflation targeting. Emerging market countries may feel obliged to wait longer after a financial crisis than industrial countries to ensure that the new inflation-targeting framework will not be threatened by financial system instability (Schaechter, Stone, and Zelmer, 2000). If an exchange rate peg is being abandoned, measures might be needed to reduce the vulnerability of the financial sector to exchange rate depreciation.

Many emerging market countries have taken measures to improve the stability of their financial systems prior to adopting inflation targeting. Strengthening the soundness of the financial system can include the resolution of insolvent financial institutions, and the adoption of sound supervisory practices. A comprehensive survey of how to move towards financial stability is provided by Folkerts-Landau and Lindgren (1998) and the references contained therein. In addition, guidance can be found in the various international standards and codes, which address the supervision and regulation of financial institutions, securities markets, and supporting infrastructure. 


\section{B. Development of Financial Markets}

Well-functioning financial markets facilitate the formulation of monetary policy under inflation targeting. Deep and liquid financial markets ensure that movements in asset prices convey information to the central bank on economic fundamentals and market expectations regarding future monetary actions. Further, deep and liquid markets help absorb shocks, thereby allowing the central bank to focus more on the inflation target as opposed to minimizing the impact of short-term shocks, or acting to preserve financial stability.

Well-functioning financial markets also contribute to the effective execution of monetary and foreign exchange operations. Central banks need to be able to conduct these transactions in large sizes without distorting prevailing market prices, in order to implement monetary policy efficiently, manage their balance sheets and the country's foreign exchange reserves, and, when required, supply credit to financial institutions in their role as lender of last resort. This is especially true for inflation-targeting central banks, which need to conduct market operations in an efficient and transparent fashion in order to keep uncertainty with respect to their operations to a minimum. Further, monetary policy is more effective when financial markets are developed enough to not be highly dollarized, since dollarization limits the impact of monetary policy.

Policymakers in countries that adopt inflation targeting should promote the development of well-functioning financial markets. Deep and liquid government security markets are especially important for effective monetary policy operations under inflation targeting (Section V.A.). World Bank-IMF (2001) discusses at length the steps policymakers can take to foster the development of government securities markets and their supporting infrastructure. Measures taken by inflation-targeting countries that were conducive to the development of government debt markets varied, depending on the state of these markets. For example, some countries sought to boost the liquidity of their markets by creating benchmark issues sometimes accelerated through bond switches or bond consolidation (Brazil, Iceland, Mexico, New Zealand, South Africa, Sweden), by establishing a formal bond exchange and a clearinghouse (South Africa), and by introducing a primary dealer system (Hungary, Mexico, South Africa).

\section{Conduct of Monetary Policy}

A central bank operating with an inflation-targeting objective must choose the appropriate monetary instruments and operating guide to pursue the inflation target. As with any operating framework, the instrument must be controllable by the central bank, and the transmission of changes in the instrument to the operating guide, and ultimately to inflation, should be as reliable as possible. There are no hard and fast rules for choosing the instruments and the operating guide because they depend on the structure of a country's financial system. 


\section{A. Monetary Operating Guide and Instruments}

The central bank may choose as its operating guide either a short-term interest rate or a monetary aggregate to influence the amount of aggregate liquidity circulating in the financial system. The operating guide can be defined as the short-term interest rate or aggregate liquidity indicator that best captures the authorities' intentions. The central bank of a country with a financial system sophisticated enough to use an inflation target should be able to influence conditions in the money market through its control of bank reserves and settlement balances held at the central bank. Conditions in the money market are typically transmitted along the yield curve to other credit markets. Examples of quantity targets are the level of aggregate or individual bank balances held at the central bank for liquidity management or payments settlements. An example of a price target would be a short-term interest rate, such as an overnight interest rate in the interbank market.

Every full-fledged inflation-targeting central bank except for Mexico uses a short-term interest rate as its operating guide, ranging in maturity from overnight to three-months (Table 4). The growing popularity of short-term interest rates as an operating target is part of the larger trend away from money stock quantitative targets (Borio, 1997; and Van't dack, 1999). New Zealand shifted from a quantitative operating target to an interest rate operating target in 1999 because the former led to undue interest rate volatility and complicated communication of the policy stance (Sherwin, 2000). The popularity of a short-term interest rate-operating guide implies that central banks have chosen to broadly accommodate fluctuations in the demand for bank reserves or settlement balances.

A central bank must also choose the instruments that will be used to set the operating guide. Direct monetary instruments (e.g., loan limits and liquidity asset ratio requirements) are rarely used by inflation-targeting central banks because they can only be adjusted infrequently. Central banks using direct monetary policy instruments should take steps to move to indirect market-based instruments before adopting inflation targeting. These steps include liberalizing key interest rates and other variables from central bank or government controls.

All inflation-targeting central banks employ market-based indirect instruments of monetary policy. Indirect instruments are better for managing liquidity on a day-to-day basis, responding quickly to inflationary shocks, signaling the policy intentions of the central bank minimizing credit risk and developing financial markets (Alexander and others, 1995). Central banks use open market operations in the form of either outright purchases/sales of government and central bank securities, or more often, reversed transactions involving domestic or foreign securities. ${ }^{7}$ Most inflation-targeting central banks execute regular

${ }^{7}$ Central banks that do not use open market operations as their primary policy instrument are those in Israel, which uses auctions of bank deposits/loans (which are similar to reversed OMOs), and Canada, which uses standing facilities to maintain a narrow interest rate corridor. 
Table 4. Operating Targets and Main Instruments of Monetary Policy

\begin{tabular}{|c|c|c|}
\hline & Operating Target & Main instruments \\
\hline \multicolumn{3}{|c|}{ Emerging Market Countries } \\
\hline Brazil & Overnight interbank rate (SELIC) & $\begin{array}{l}\text { Open market operations (OMOs) using Treasury Bonds or } \\
\text { bonds issued by the central bank }\end{array}$ \\
\hline Chile & $\begin{array}{l}\text { Real overnight interbank rate tied } \\
\text { to CPI with } 20 \text {-day lag }\end{array}$ & OMOs through issuance of central bank paper and repos \\
\hline Colombia & Overnight repo rate & OMOs with repos and government securities \\
\hline Czech Republic & Two-week interbank rate & Daily two-week repo operations \\
\hline Israel & $\begin{array}{l}\text { Interest rate on short-term loans to } \\
\text { and deposits from banks }\end{array}$ & $\begin{array}{l}\text { Fixed-term and daily auctions for deposits from banks, } \\
\text { ovenight discount window loans to banks, and OMOs with } \\
\text { treasury bills }\end{array}$ \\
\hline Hungary & Short-term interbank rales & $\begin{array}{l}\text { Weekly auctions of two-week central bank deposits and } \\
\text { three months central bank bills }\end{array}$ \\
\hline Korea & Overnight interbank rate & OMOs wilh government securities \\
\hline Mexico & $\begin{array}{l}\text { Aggregate commercial bank current account } \\
\text { balance with the central bank }\end{array}$ & OMOs with government or central bank securities \\
\hline Poland & 28-day National Bank of Poland bill rate & OMOs with central bank bills \\
\hline South Africa & Overnight interbank rate & OMOs with government securities \\
\hline Thailand & Two-week repo rate & OMOs with repos \\
\hline \multicolumn{3}{|l|}{ Industrial Countries } \\
\hline Australia & Overnight interbank rate & $\begin{array}{l}\text { OMOs with repos and outright transactions, and foreign } \\
\text { exchange swaps }\end{array}$ \\
\hline Canada & Overnight rate & Operating band enforced through standing facilities \\
\hline Finland & Short-term money market rate & $\begin{array}{l}\text { OMOs with government securities (monthly repos and } \\
\text { outright OMOs) }\end{array}$ \\
\hline Iceland & Short-term money market rate & OMOs with repos \\
\hline New Zealand & Overnight interbank rate & $\begin{array}{l}\text { OMOs with repos and outright transactions, and foreign } \\
\text { exchange swaps }\end{array}$ \\
\hline Norway & Overnight interbank rate & $\begin{array}{l}\text { OMOs with fixed rate deposits and fixed rate collateralized } \\
\text { loans }\end{array}$ \\
\hline Spain & Overnight interbank rate & OMOs with government securities and central bank paper \\
\hline Sweden & One-week interbank rate & OMOs with repos \\
\hline United Kingdom & Two-week interbank rate & OMOs with repos \\
\hline
\end{tabular}

Sources: Central bank websites, Borio (1997), Van't dack (1999), and Landerretche, Morandé and Schrnidt-Hebbel (1999). 
repurchase and outright transactions to cover the bulk of liquidity needs; their timing and, sometimes, maturity are closely tied to the characteristics of the required reserve maintenance period. Irregular transactions are occasionally employed to make the necessary fine-tuning adjustments to the volume of liquidity as dictated by evolving circumstances. The modalities of OMOs can be designed to facilitate policy signalling. For example, the Bank of Finland moved from variable to fixed rate tenders to make signalling more explicit, and applied a full allocation to address the problem of overbidding.

Most inflation-targeting countries adjust their short-term interest rate operating guide in response to deviations of inflation or expected inflation from the target and the output gap. Central bank interest rate setting behavior can be characterized as a Taylor rule under which interest rates are adjusted in response to deviations of current and lagged variables, such as inflation and the output gap. Under inflation targeting, interest rate response functions are more forward-looking than in other policy frameworks, owing to the lags between policy actions and the inflation outcome, and the desire to avoid excessive output volatility (Isard, Laxton and Eliasson, 2000; and Armour and Côté, 2000). In Brazil, the central bank employs three interest rate response functions in its model simulations: an exogenous interest rate path, a Taylor rule with linear combination of system variables, and interest rate paths generated by optimal response functions. In practice, central banks complement such an approach with judgment that uses all information pertaining to the inflation forecast. Emerging market central banks often must rely on more qualitative information because, if they have developed models, these are typically subject to more uncertainties than those of industrial countries.

Most central banks prefer to operate from a starting point of being a net supplier of funds to the monetary market (i.e., a liquidity shortage in the market). As a net supplier of funds the central bank is effectively a monopolist and therefore has more influence on the marketparticularly interest rates. In contrast, when the central bank is borrowing from the money market it must compete with other borrowers and therefore may have less influence over the interest rate. Many emerging market inflation-targeting countries begin with structural liquidity surpluses because the same developments that make these countries suitable for inflation targeting also lead to heavy capital inflows, which can only be partially sterilized. To shift from a net creditor to a net debtor position, central banks in the Czech Republic and Poland have taken steps to make their holdings of government securities tradable and have also begun issuing central bank securities so that they can absorb the excess liquidity in their financial systems. Another step that could be considered is adjusting reserve requirements to raise the average demand for reserves, thereby turning an autonomous surplus into a net liquidity deficit.

Stability of the demand for payment settlement balances is a key element in the design of monetary policy. The demand for settlement balances can be unstable, especially at the aggregate level, if banks fail to actively manage their positions, and in the presence of technical or behavioral impediments to a smooth redistribution of reserves in the system (Borio, 1997). This is especially true in emerging market countries that have concentrated banking systems, and structural imbalances that cause the same banks to be on one side of 
the market on a regular basis. A very interest inelastic, and possibly unstable, demand for settlement balances calls for active management of the supply of liquidity by the central bank on a daily basis if large fluctuations in the short-term interest rate are to be avoided. This puts a premium on signaling mechanisms aimed at guiding the interest rate.

The central bank can play a role in developing and supervising sound and efficient payment, securities settlement, and clearing systems, which facilitate the operation of monetary policy. While a well-functioning infrastructure is important under any monetary policy regime, it is particularly important for inflation-targeting central banks, since disturbances could cloud the public's ability to interpret the stance of monetary policy. Examples of inflation-targeting emerging market countries that have reformed their payment systems are Brazil, the Czech Republic, Poland, and South Africa.

\section{B. Transmission of Monetary Policy}

For inflation targeting to work, the central bank needs to be able to set its monetary instruments to steer inflation toward the target. The transmission mechanism of monetary policy is the connection between changes in the monetary stance and their effect on the operating target, and ultimately, inflation. The stronger the transmission links, and the better they are understood, the more effective will be changes in monetary instruments aimed at attaining the inflation target.

The transmission of monetary policy from an interest rate operating guide to inflation operates through several channels. An increase in the operating interest rate in an open economy can be expected to reduce inflation by:

- appreciating the exchange rate, thereby quickly lowering the price of imported goods in domestic currency;

- raising the cost of bank and nonbank borrowing, thus dampening investment and durable goods consumption, and increasing the output gap;

- lowering wealth from a higher discount rate, thereby reducing consumption;

- reducing corporate net worth, thus leading banks to cut bank lending;

- decreasing investment and durable consumption; and

- increasing bankruptcies of highly leveraged firms, thereby worsening expectations of economic activity.

The uncertainty inherent in the transmission of monetary policy to inflation is one of the principal challenges faced by inflation-targeting central banks, especially for emerging market countries. 
The empirical literature stresses that country-specific structural features of the financial system are crucial. The impact of an increase in the policy rate on commercial bank interest rates is lower in countries where: (i) the banking system is dominated by public banks, (ii) entry barriers often restrict bank competition (e.g., such as constraints on the opening of new branches), (iii) there are capital controls, (iv) there are volatile money market rates (Cottarelli and Kourelis, 1994), and (v) capital inflows are volatile. Emerging market countries with higher inflation rates seem to have transmission channels characterized by downward price stickiness and rapid pass-through from the exchange rate to inflation.

Central banks do have policy instruments available to strengthen, or at least improve their understanding of the transmission channels of monetary policy. Financial reforms to improve the operation of money markets and tighten the links between money markets and other financial markets will strengthen transmission channels. As discussed elsewhere in the paper, measures to improve the transparency of monetary policy minimize surprises to the market that could effectively weaken transmission. The allocation of internal central bank resources to economic analysis can help enhance understanding of the channels of monetary transmission, and thus help improve the formulation of policy. Better bank and corporate balance sheet data collection by government agencies can also help the central bank improve its understanding of monetary transmission. Intensive and regular contacts with money and financial market participants can assist the central bank in anticipating the effect of policy changes on inflation.

\section{Inflation Forecasting}

Inflation forecasting plays a key role in an inflation-targeting framework. In this framework the stance of monetary policy is adjusted whenever there is evidence that future inflation might differ persistently from the target path. If the inflation forecast over the policy horizon suggests that inflation will be systematically above or below its target, the stance of monetary policy would need to be tightened or eased now. Indeed, the inflation forecast can be considered the intermediate policy target.

The central bank's inflation forecasts should make use of all available information on the outlook for inflation. Unlike an exchange rate peg or a simple monetary aggregate rule, the central bank's attention is not limited to only one variable as an indicator or predictor of inflationary developments. ${ }^{8}$ Consequently, prospective inflation targeters should be confident that that they can obtain enough reliable information on the outlook for inflation to enable them to present inflation forecasts that will be considered credible in the eyes of financial market participants and the public.

\footnotetext{
${ }^{8}$ Although in the case of monetary targeting, central banks often must examine and take account of other variables that are thought to affect velocity, when setting or adjusting the monetary target. The case for a simple monetary rule (e.g., constant growth rates) rests on the empirical judgment that changes in the demand for money are difficult to predict from current information and are likely to be offsetting over time.
} 
The centrality of inflation forecasts in the conduct of monetary policy can represent a major challenge for countries seeking to engage in inflation targeting. Many emerging market countries that have successfully completed the transition to inflation targeting had to shift from an operating environment heavily influenced by controls and regulations to focus more on policy formulation. Moreover, while many of them already had experience in building economic models, their staff lacked "hands-on" experience in working with forward-looking models of inflation, gathering qualitative information on economic conditions, and assessing judgmentally the outlook for inflation and the appropriate policy response in an inflation-targeting framework. Central banks seeking to engage in inflation targeting need to be able to complement the information gleaned from monetary and credit aggregates with that obtained from other leading indicators of inflation. Some of organizational changes central banks have made to support inflation targeting are described in Box 1.

A fundamental step in broadening the information upon which monetary decisions are based is building databases. Economic indicators that can be used to form a view on the inflation outlook include simple inflation indicators collected and analyzed by authorities or the private sector, as well as leading indicators constructed by central banks that are thought to preview changes in inflation. ${ }^{9}$ They may involve aggregate demand and supply variables, monetary aggregates, interest rates and exchange rate measures, inflation, price and expectations measures. Surveys of inflation expectations, interest differentials and yields on government bonds (indexed or not to inflation) are some useful indicators that are widely used. Monetary and credit indicators may also represent a rich source of information about expected inflation in developing and emerging countries (Appendix II).

Using statistical relationships for forecasting purposes and ultimately building forecasting models are further steps that should be taken over time. ${ }^{10}$ Appendix II summarizes the indicators and models used by the current inflation-targeting central banks to forecast future inflation. Prospective inflation-targeting central banks can profit from the experiences of their predecessors by using the models and indicators developed by current inflation targeters, and recalibrating them to take account of their specific country circumstances. One reason why Brazil was able to adopt inflation targeting fairly quickly was that it was able to take advantage of inflation forecasting models and policy analysis frameworks developed by central banks in countries that had gone before it down the inflation-targeting path. Over time, more elaborate forecasting models can be developed as central banks gain a better

${ }^{9}$ Chauvet (2000) analyzes the different leading indicators developed by the Central Bank of Brazil.

${ }^{10}$ Laxton and Scott (2000) provide a basic plan and critical path for developing such a system. 


\section{Box 1. Organizational Changes at Central Banks Adopting Inflation Targeting}

The need to supplement the information obtained from economic indicators and models with judgment may require important changes in the decision-making processes of prospective inflation targeters. Developing judgment can be fostered by involving people with a diversity of backgrounds in the decision-making process. A number of inflation-targeting central banks have redesigned their governance structures to allow for the direct participation of non-career central bankers in the monetary policy decision-making process in either a full or part-time capacity. While this trend is not necessarily directly linked to the adoption of inflation targeting, it does help to ensure that a broader range of perspectives is taken into account in the decision-making process. For many emerging market countries, employment of non-career central bankers on a full-time basis could also be a useful way for a central bank to make full use of the leadership talents available to it.

The building of new relationships with officials from key economic sectors may also enhance the conduct of monetary policy under inflation targeting. Many central banks - not just inflation-targeting ones-have sought to forge relationships with officials from a wide range of institutions, including companies, industry associations, labor unions, and universities. In addition to helping to promote a better understanding of monetary policy objectives and the rationale underpinning monetary policy stances, such contacts can be used to supplement the advice provided by economic models with real time qualitative information on domestic economic conditions.

The move toward inflation targeting has often been accompanied by major reforms to organizational structure and an emphasis on increased delegation of authority. Although not directly related to the introduction of inflation targeting, there has been a major cultural evolution in the Central Bank of Chile from an environment that emphasized explicit controls and regulatory oversight of the financial system to one that focuses on banking supervision and policy formulation (Central Bank of Chile website). This factor, combined with major advances in technology and management theory, led the central bank to adopt a more flexible organizational structure, which is less hierarchical and emphasizes decentralization of decision-making authority. Similarly, the Bank of Israel notes that the move away from a monetary policy framework that focused on directed credit, state loans, and foreign exchange controls led it to undergo a major restructuring in the mid-1980s (Bank of Israel website).

The adoption of inflation targeting by emerging market countries has often been accompanied by a major shift in the focus of central bank economic analysis and staffing requirements. The introduction of inflation targeting does not appear to have had major implications for central bank resource requirements in industrial countries, since many of these central banks were already weil endowed with analytic resources dedicated to advancing the banks' understanding of their economies and monetary transmission mechanisms. In contrast, some emerging market country central banks have had to enhance their analytic capacities and re-orient their economic analysis and data management activities toward gathering the data, building the models needed to generate regular inflation forecasts, and identifying the main transmission channels from short-term interest rates to inflation. For example, the South Africa Reserve Bank has been actively looking to recruit and train new staff that could help it improve its economic monitoring and model-building abilities so that it can develop a framework for forecasting inflation and determining the appropriate policy settings. In Brazil's case, the adoption of inflation targeting was accompanied by a decision to attract staff with strong skills in economics and modeling techniques-a decision which helped to focus the economic analysis and research activities in the central bank, now dedicated to building the models needed to forecast inflation and improve the central bank's understanding of the monetary transmission mechanism (Leone, 1999). Similar needs have also been identified for emerging market countries that are thinking of adopting inflation targeting in the future.

Inflation targeting also seems to have changed the role played by staff involved in monitoring financial markets. Prior to the adoption of inflation targeting, those involved in financial market activities, particularly in central banks with fixed exchange rate regimes, played an active role in monitoring markets on a continuous basis, and executing transactions to ensure that interest rate and exchange rate objectives were achieved. With the advent of inflation targeting, there appears to have been a shift in roles for such staff. In inflation targeting, the focus of monetary policy is squarely on the medium term rather than on day-to-day developments in financial markets. As a result, those engaged in monitoring markets now spend more time extracting information on the market's expectations for future inflation and monetary policy stances, and correspondingly less on monitoring the continuous flow of transactions through the markets. 
understanding of the underlying economic relationships at play in their economies. The forecasting and policy analysis system and core model provide the common language in which the central bank's staff and management can discuss economic conditions and monetary policy, and ultimately explain the policy actions of the central bank to the public. Models can never replace judgment by the policy makers, and judgments will always play a large role in determining policy.

In addition to using models and indicators for forecasting inflation, inflation-targeting central banks should collect as much information as possible from discussions with private sector officials and financial market participants. These discussions should seek to obtain information on the state of the economy and the implications for future inflation and may also provide additional insight into private-sector inflation expectations. These discussions are particularly useful in countries where economic relationships are changing rapidly, and financial markets are less developed.

\section{Exchange Rate Policies}

The inflation target must take precedence over an exchange rate objective. Inflation targeting central banks should take care not to target both the nominal exchange rate and the inflation rate-that is, to try and influence the real exchange rate--even in the presence of competitiveness concerns or current account pressures. The reason is that in the medium and long run, monetary policy affects the nominal, not the real exchange rate. Thus, corrections needed to a country's external position are best dealt with through fiscal policy or structural policies.

However, smaller open countries, especially those with thin foreign exchange markets, may need to intervene or adjust interest rates to limit the effect of temporary exchange rate shocks on inflation and financial stability (Mishkin and Schmidt-Hebbel, 2001). On occasion, pressures in the foreign exchange market may cause the exchange rate to move too far or too fast. In practice, all inflation-targeting central banks explicitly allow for the option of intervening in foreign exchange markets, although industrial countries have rarely done this in recent years (Table 5). Foreign exchange interventions appear to be somewhat more frequent for emerging market countries, which typically have thinly-traded currencies, and are thus more susceptible to disturbances emanating from the foreign exchange market.

Interest rate adjustments are also used to help stabilize the exchange rate. The central bank may need to direct or allow interest rates to move sharply to levels likely to stabilize expectations, even if the new level may not (in the short run at least) appear consistent with achievement of the inflation targets, which can reflect shifts in the pass-through from the exchange rate to inflation. This was the case in Chile and Israel during the Asian/Russian crisis in 1998, and in South Africa during late 2001. 
Table 5. Inflation Targeting Country Central Banks, Publicly Reported Information on Foreign Exchange Market Intervention Practices, 2001

\begin{tabular}{|c|c|c|}
\hline & Intervention Practices & Sources \\
\hline \multicolumn{3}{|c|}{ Industrial countries } \\
\hline Australia & $\begin{array}{l}\text { The Reserve Bank of Australia intervenes when the exchange rate is overshooting; } \\
\text { and when market conditions are unsettled. }\end{array}$ & IMF Country Report 01/162 \\
\hline Canada & The Bank of Canada intervenes only in exceptional circumstances. & Bank of Canada Annual Report, 2000 \\
\hline Iceland & $\begin{array}{l}\text { The Central Bank of Iceland intervenes only to adhere to inflation target or sees } \\
\text { exchange rate fluctuations as a potential threat to financial stability. }\end{array}$ & $\begin{array}{l}\text { Monetary Bulletin of the Central Bank of } \\
\text { lceland, November } 2001\end{array}$ \\
\hline New Zealand & $\begin{array}{l}\text { The Reserve Bank could intervene directly in the foreign exchange market to } \\
\text { counteract "disorderly market conditions"; in practice the Reserve Bank has not } \\
\text { intervened since } 1985 \text {. }\end{array}$ & $\begin{array}{l}\text { Reserve Bank Governor speech, October } \\
2000\end{array}$ \\
\hline Norway & $\begin{array}{l}\text { The Central Bank of Norway intervenes when the currency moves significantly out } \\
\text { of line with reasonable fundamentals and at the same time exchange rate } \\
\text { developments impair the prospects of achieving the inflation target. Interventions } \\
\text { may also be necessary in the cvent of large short-term fluctuations of the currency } \\
\text { when forcign exchange market liquidity is reduced. }\end{array}$ & Annual Report, 2001 \\
\hline Sweden & $\begin{array}{l}\text { The Riksbank intervened in the currency market in June 2001, for the first time in } \\
\text { years, to limit the impact of a sudden depreciation on inflation. }\end{array}$ & $\begin{array}{l}\text { Central Bank First Deputy Governor speech, } \\
\text { September } 2001\end{array}$ \\
\hline United Kingdom & The Bank of England can intervene in the foreign exchange market. & $\begin{array}{l}\text { Bank of England fact sheet on Foreign } \\
\text { Exchange Market, Bank of England website }\end{array}$ \\
\hline \multicolumn{3}{|c|}{ Emerging market countries } \\
\hline Brazil & $\begin{array}{l}\text { The Central Bank do Brasil may intervene on a regular basis, to adhere to the } \\
\text { inflation target, or in exceptional situations. }\end{array}$ & $\begin{array}{l}\text { IMF Press Release No. } 01 / 38 \text {, Sept. } 2001 \\
\text { and Central Bank do Brasil Annual Report, } \\
2000\end{array}$ \\
\hline Chile & $\begin{array}{l}\text { The Central Bank of Chile has the authority to intervene in exceptional } \\
\text { circumstances; these interventions must be publicly announced and justified. }\end{array}$ & Central Bank of Chile Annual Report 2000 \\
\hline Colombia & $\begin{array}{l}\text { The Banco de la República does not intervene in the exchange market to define a } \\
\text { particular exchange rate, although auctions of foreign currency sale options are } \\
\text { used to accumulate international reserves. }\end{array}$ & Report to the Parliament, July 2001 \\
\hline Czech Republic & Interventions only to moderate large fluctuations in the exchange rate. & MF Country Report 01/112 \\
\hline Hungary & $\begin{array}{l}\text { The National Bank of Hungary intervenes to maintain the forint in a }+/-15 \text { percent } \\
\text { band. }\end{array}$ & National Bank of Hungary website \\
\hline Israel & $\begin{array}{l}\text { The Bank of Isracl has not intervened since 1997, allowing market forces to } \\
\text { determine the appropriate level of the exchange rate within the exchange rate band. } \\
\text { (The width of the band against a basket of currencies is } 39.2 \text { percent.) }\end{array}$ & $\begin{array}{l}\text { Bank of Israel, Foreign Currency } \\
\text { Department, } 2000 \text { Annual Report and IMF } \\
\text { Country Report } 01 / 133\end{array}$ \\
\hline Korea & The Bank of Korea has intervened in the foreign exchange market in recent years. & IMF Public Information Notice 01/8 \\
\hline Mexico & The Banco de Mexico lets the peso float freely. & IMF Country Report 01/77 \\
\hline Poland & A pure floating exchange rate regime has been in place since April 2000. & IMF Country Report $01 / 56$ \\
\hline South Africa & $\begin{array}{l}\text { The Reserve Bank did not intervene in the foreign exchange market during } 2000 \\
\text { except to buy foreign exchange to lower the net open foreign exchange position. }\end{array}$ & IMF Public Information Notice 01/44 \\
\hline Thailand & Direct foreign exchange intervention is limited. & Bank of Thailand website \\
\hline
\end{tabular}


Inflation-targeting central banks should make clear that policies to influence the exchange rate are aimed at smoothing the effect of temporary shocks and attaining the inflation objective. Policies to influence the exchange rate include market interventions and changes in the interest rate. Transparency helps reassure markets that policies aimed at influencing the exchange rate are intended to limit solely the impact on inflation and maintain financial stability, as opposed to pursuing an exchange rate objective. For example, many inflation-targeting central banks use one set of instruments to signal the stance of monetary policy, and others for day-to-day liquidity management operations that are not meant to contain any policy content. There is a growing consensus that sterilized foreign exchange intervention's most useful role is as a signal that the authorities' stand ready to alter more fundamental policies, including the stance of monetary policy, if exchange rate pressure continues ("signaling channel") (White, 1999). Such intervention need not be large, but should be publicly known and used only intermittently, and it must be followed up by other policy changes (if need be) to ensure the credibility of future intervention. Meanwhile, transactions undertaken to supply the government with foreign exchange for commercial purposes or for foreign reserves management purposes might best be undertaken in a more mechanistic fashion; the Bank of Mexico's auctioning of options to purchase foreign exchange could provide lessons in this regard (see Banco de Mexico). ${ }^{11}$

The experiences of Chile and Israel also may offer some practical lessons. When they first began their transition towards inflation targeting, they were also operating with exchange rate bands. The exchange rate could be viewed as entering independently into the objective function of policymakers owing to its importance for the real sector and for exchange rate stability in these open economies. Both countries used foreign exchange intervention to keep the exchange rate within their pre-announced crawling bands, which helped monetary policy to focus on achieving the inflation targets. Over time, the bands were widened until they did not serve as a constraint on monetary policy, barring exceptional circumstances. Today, Israel and Hungary maintain exchange rate bands wide enough to afford scope for fullfledged inflation targeting.

\section{E. Coordination Issues}

Policymakers in inflation-targeting countries should understand the ways in which the different policy instruments operate, their potential to reinforce one another, and how policy

11 The Bank of Mexico followed a predefined rule to purchase U.S. dollars prior to July 2001. The goal was to acquire foreign reserves in a manner that minimized effects on the exchange rates. It auctioned options on a monthly basis, which permitted the banks to sell to it a predetermined amount of U.S. dollars. The strike price was not fixed, but if the option was used the previous day's exchange rate was applied. Moreover, the option could only be used when the strike price was not higher than the arithmetic moving average of the previous 20 working days. These characteristics helped minimize the risk that exercising the options might put additional pressure on the peso when it was depreciating. 
tensions can arise (Sundararajan, Dattels and Blommestein, 1997). Debt management, fiscal and monetary policies can reinforce one another in helping to lower the risk premium in the structure of long-term interest rates, or in the case of many emerging market countries, simply help to foster the emergence of a market for government securities. The central banks can help to bring this about by informing the fiscal authorities of the effects of government debt levels on the achievement of their monetary objectives. In some cases, conflicts between debt management and monetary policies can arise owing to their different objectives-debt management focuses on the cost/risk trade-off, while monetary policy is directed towards achievement of the inflation targets. For example, some central banks may prefer that the government issue inflation-indexed debt or borrow in foreign currency to bolster the credibility of monetary policy, while debt managers may believe that the inflation-indexed debt and that foreign currency debt introduces greater risk onto the government's balance sheet.

Clarity in the roles and objectives for debt management and monetary policy minimizes potential conflicts. As emerging market inflation-targeting countries are able to develop market-based monetary instruments, they should promote a separation of monetary policy from debt management by having the central bank operate in the secondary market to manage its balance sheet, rather than using the primary market. This helps to demonstrate to the public that monetary policy decisions are not being driven by debt management considerations. By the same token, debt management objectives should not be seen as a justification for the extension of low-cost central bank credit to the government.

An inflation-targeting central bank needs to ensure that operations in different markets do not send conflicting messages or generate uncertainty regarding its policy intentions. Clarity in the policy message is especially important when economic and financial conditions are unsettled, and market participants and the public are looking to the central bank for leadership in interpreting the implications for the appropriate stance of monetary policy. Market participants and the public are constantly scrutinizing the central bank's activities for whatever clues that become available regarding changes to the central bank's outlook for inflation and the implications for future changes in its policy stance. Emerging market inflation targeters are especially likely to confront these situations, since their financial systems tend to be more likely to be buffeted by abrupt shifts in international capital flows, and the need to intervene more regularly in foreign exchange markets to maintain orderly market conditions.

Inflation targeting countries have made efforts to strengthen the coordination between public debt management and monetary policy. While in several countries public debt is managed by a separate debt management agency (e.g., New Zealand, Sweden, United Kingdom) or a unit in the Ministry of Finance (e.g., Mexico, Poland, South Africa), the central bank often retains roles such as issuing agent, registrar, and clearing and settlement agent. The objectives and roles of the debt management agencies have been clearly defined, and the central bank's role as a fiscal agent is usually well specified. Coordination and an exchange of information take place between these agencies and the central bank in regular high-level policy committees (e.g., Brazil, South Africa, Poland). Information on the government's liquidity needs is 
usually exchanged on a daily basis. In countries where the central bank issues its own securities, the maturity of central bank paper generally differs from those of government securities (e.g., Poland), and issuance of central bank securities is usually coordinated with that for government securities. 


\section{INFLATION TARGET DESIGN}

Inflation targets are designed based on country-specific factors such as the degree of central bank credibility, the country's vulnerability to shocks, and/or data availability. More detailed discussions of pros and cons of various inflation target designs and country experiences can be found in Bernanke and others (1999) and Schaechter, Stone, and Zelmer (2000).

\section{Price index}

The choice of the appropriate price index can be framed in terms of the trade-offs between controllability and credibility. There is no viable alternative to a consumer price index (CPI) because it is the best and most up-to-date price index available, the focus of expectations, easily understood by the public, and perceived to be less susceptible to manipulation by the central bank. However, because the CPI often includes components that are beyond the control of the central bank (such as administrative prices, terms of trade, and indirect taxes), some central banks address this problem by using a core CPI that excludes some or all of these factors. Compilation of the CPI and core inflation by an independent agency, typically the country's statistical agency, can improve credibility by avoiding the perception that the central bank manipulates the data. The Bank of Finland outsourced the construction of the core CPI to the statistical office. Most emerging market countries use the CPI because it is familiar to the public and therefore enhances credibility. However, it is important that the core and total CPI measures move together in the long run in order to ensure that the chosen inflation target reflects the public's purchasing power.

\section{Target range or point}

A target range rather than a point can provide the central bank with more flexibility to respond to shocks and permit a range of discretion in the context of other objectives. Clearcut target breaches are less likely. Moreover, the width of the range signals in advance how much tolerance the central bank has for fluctuations in inflation around the mid-point, recognizing that a point will not be hit exactly. The trade-off between a narrow and a wide range depends on the frequency and severity of shocks that typically hit the economy and the central bank's credibility. To provide clear guidance for inflation expectations, most central banks have set either point targets or narrow target ranges of two percentage points or less (see Table A1). These arrangements are favored by industrial and emerging market economies alike. Important exceptions are Brazil, New Zealand, and South Africa, which have opted for wider ranges to compensate for their targeted price indices including a number of volatile items that are beyond the influence of the central bank. An argument can be made that a point target can help lower inflation by concentrating inflation expectations to the long-run target (Isard and Laxton, 2000).

\section{Escape clauses}

Escape clauses set the conditions under which inflation target breaches might be tolerated and indicate the time frame over which the central bank would attempt to return to the 
inflation target path or communicate a new target path. The choice of design of escape clauses involves trading off flexibility and credibility. Currently, Canada, the Czech Republic, New Zealand, South Africa, and Sweden have escape clauses in their inflation-targeting frameworks. Among the downsides of these clauses are their largely discretionary invocation and their inability to capture all potential shocks. Attempts to use them in situations that are not clear-cut could undermine the accountability and credibility of the inflation-targeting framework. In any case, breaches of the inflation target should be signaled by the central bank as far ahead of time as possible. Further, the central bank should indicate how it would react to the breach, including whether or not the first round effect on prices will be tolerated.

\section{Target horizon}

For countries with inflation above the long-run inflation target rate, short-target horizons can accelerate the pace of disinflation. Monetary policy can respond to shocks by adjusting the inflation target itself, rather than just the policy stance, which can leave more room to absorb short-run inflationary shocks and dampen output fluctuations. Many emerging market countries have spelled out a disinflation path defined by annual targets in addition to their long-run inflation objective. The entire path is either announced several years in advance (e.g., Czech Republic) or year-by-year (e.g., Poland), or the long-term target can be announced several years ahead of time (e.g., Colombia) to anchor inflation expectations.

When inflation is at the desired long-run objective, the length of the policy horizon often reflects policy transmission lags and a desire to avoid excessive variations in monetary instruments and consequently output. The target horizon defines the period over which the central bank commits to achieving the targeted inflation rate. For Australia, Chile (beginning in 2001), New Zealand, Sweden, and the United Kingdom, which set targets at or near their longer-run desired rate of inflation, the horizon is more than one year. Long-term horizons have the advantage of giving the central bank more scope to respond to shocks (e.g., to keep output stable) and help establish inflationary expectations. Indeed, short target horizons and lead times may generate instrument instability, especially with respect to the exchange rate, if the horizon is short in relation to policy lags. 
Table A1. Inflation Target Design: Country Experiences

\begin{tabular}{|c|c|}
\hline & Countries \\
\hline \multicolumn{2}{|l|}{ Price Index } \\
\hline Consumer price index (CPI) & $\begin{array}{l}\text { Australia 1/ Brazil, Canada, Chile, Colombia, Hungary, } \\
\text { Iceland, Israel, New Zealand } 2 / \text {, Norway, Poland, Spain, } \\
\text { Sweden }\end{array}$ \\
\hline Core/Underlying CPI & $\begin{array}{l}\text { Czech Republic, Finland, Korea, South Africa 3/, Thailand, } \\
\text { United Kingdom 3/ }\end{array}$ \\
\hline \multicolumn{2}{|l|}{ Point target or target range } \\
\hline Point target & $\begin{array}{l}\text { Colombia, Finland, Mexico 4/, Norway, Spain, } \\
\text { United Kingdom }\end{array}$ \\
\hline Point target with a range & Brazil, Hungary, Iceland, Korea, Sweden \\
\hline Target range of 2 percentage points or less & Australia, Canada, Chile 5/, Czech Republic, Israel, Poland \\
\hline Target range of more than 2 percentage points & New Zealand, South Africa, Thailand \\
\hline \multicolumn{2}{|l|}{ Target horizon for inflation targets } \\
\hline Annual targets & Korea 7/, Mexico, Poland, South Africa \\
\hline $\begin{array}{l}\text { Annual targets, but announced several } \\
\text { years in advance }\end{array}$ & Brazil, Colombia, Czech Republic, Hungary, Spain, Thailand 6/ \\
\hline Indefinite horizon & $\begin{array}{l}\text { Australia 8/, Canada 9/, Chile 10/, Finland, Iceland, Israel 11/, } \\
\text { New Zealand } 12 / \text {, Norway, Sweden, United Kingdom }\end{array}$ \\
\hline
\end{tabular}

Sources: Bernanke and others, 1999; central bank websites.

1/ Australia switched from a core measure to the CPI in 1998 when the latter was redefined by the statistical agency to exclude interest charges.

2/ New Zealand switched from a core measure to the CPI in 1999 when the latter was redefined by the statistical agency to exclude interest charges and section prices.

3/ South Africa and the United Kingdom only exclude mortgage interest payments from their price index (retail price index in the case of the United Kingdom).

4/ The inflation target is equal to less than the announced point target.

$5 /$ Chile began this target range in 2001.

6/ Thailand's targets are measured as a quarterly average over $2000-2002$.

$7 /$ Korea has also announced a mid-term target.

8/ The inflation target for Australia is measured on average over the economic cycle.

9/Canada has a multi-year target that is reviewed periodically.

$10 /$ Chile's target horizon became "indefinite" beginning in 2001.

11/In August 2000 the Israeli government set targets for 2001 and 2002, as well as a target of 1-3 percent for 2003 indefinitely onwards.

12/ New Zealand has an essentially indefinite horizon, although the target agreement expires when the Governor's term ends. 


\section{INFLATION FORECASTING}

In an inflation-targeting framework, the inflation forecasts can be viewed as the intermediate guide for monetary policy (Svensson, 1997; Bogdanski, Tombini and da Costa Werlang, 2000). Emerging market countries rely less on statistical models to forecast inflation owing to data shortfalls, ongoing structural changes, and their vulnerability to shocks. Moreover, it is important to remember that in the early days of inflation targeting a central bank should expect the observed economic relationships to change as the inflation-targeting framework gains credibility and inflation becomes more firmly anchored to the targets. Thus, it is more important for a central bank's forecasting models to be well grounded in economic theory, rather than reflective of previously observed econometric relationships.

Many inflation indicators are common to all inflation-targeting countries. An inflation indicator refers to observable data that have been previously shown to provide useful signals regarding future changes in inflation. Indicators include aggregate demand and supply variables, monetary aggregates, interest rate and exchange rate measures, inflation, price measures, and expectations (see Table Al for an overview of indicators used). Surveys of inflation expectations conducted by the private sector or even by the central bank itself are useful in the inflation-targeting regime. Surveys can directly sample market and consumer inflation expectations (New Zealand), or the central bank can summarize surveys of market inflation expectations (United Kingdom). Qualitative surveys of private sector conditions are utilized in Canada and New Zealand. In addition, informal canvassing of market participants by central bank staff can provide useful information.

Yields on government bonds indexed to inflation can be a useful indicator (Price, 1997). Movements in the spread between the yields on indexed and non-indexed bonds have been used by the central banks of Australia, Canada, Iceland, Israel, New Zealand, and the United

Kingdom to gauge the impact of policy changes and other developments on inflation expectations and/or the inflation risk premium. (South Africa issued its first indexed government bonds in March 2000.) These data should be used with care, however, because the market for indexed debt is thin and there may be large and variable risk premiums. Moreover, in some countries technical issues, such as tax treatment of returns on indexed debt compared with nominal debt can complicate the extraction of information on inflation expectations. Expected future inflation rates can also be derived from nominal and real forward interest rates (Söderlind and Svensson, 1997).

For emerging market countries, aggregate demand and supply indicators have greater weight. The greater weight of these indicators reflects the importance of real shocks and the lack of alternative market-based indicators. Supply shocks seem to be especially important for middleincome emerging market countries (Agénor, McDermott and Prasad, 1999). Emerging market countries can benefit from the introduction or refinement of inflation indicators. Several central banks have worked with statistical agencies to define core measures of inflation that provide information on trend movements of inflation. Central banks can also identify or develop new inflation indicators based on market conditions. 
The structural models used by central banks to forecast inflation have important common elements. These include an open economy demand curve, a Phillips curve, an international asset market equilibrium condition, and a monetary policy reaction function (Bogdanski, Tombini and da Costa Werlang, 2000; Clinton, 2000). These elements have been used extensively in empirical work on central bank behavior, monetary policy rules, and sacrifice ratios (Taylor, 1999). Also, they lie at the heart of some of the new large macro-econometric models developed in central banks, including the Bank of Canada's Quarterly Projections Model (QPM) and the U.S. Federal Reserve Board's FRB/U.S. model.

Large-scale macroeconomic models are used by several industrial countries. These models can serve as useful guides to policy for countries that have had inflation targeting in place for some time and have economic relationships that are not being obscured by major structural changes associated with industrialization. Canada and New Zealand use large dynamic models to produce forecasts (Drew and Hunt, 1998). These models are calibrated to provide theoretically plausible simulation results because the parameters generated by estimation on the basis of a good fit to historical data proved to be less useful for conducting policy simulations due to the fact that economic relationships change as inflation expectations become increasingly anchored to the target. Development of large-scale models has taken many years, notwithstanding the relatively long period of time that inflation targeting has been in place. Most industrial countries also utilize small structural models that capture a particular sector or key variable to assess developments in key sectors (Drew and Hunt, 1998). The latter are especially useful starting points for monitoring expected developments over the near term, say one or two quarters.

Several industrial countries use satellite models of important sectors. The models permit the investigation of specific issues affecting the inflation forecast, e.g., supply shocks, and at the same time help keep the core model simple.

Emerging market countries, in contrast, rely less on quantitative models. This is because the years of experience with inflation targeting are too few to generate reliable estimates of such a model, and because of ongoing changes in structural relationships as their economies industrialize (Leone, 1999; Leiderman and Bar-Or, 2000). However, most emerging market inflation-targeting central banks have found it worthwhile to devote extra resources to development of such models for greater future use. Brazil, the Czech Republic, and Israel all work with three or four equation models drawing on the theoretical relationships found in models used by industrial country central banks (Bogdanski, Tombini and da Costa Werlang, 2000; Clinton, 2000). Models can facilitate monetary policy in important ways other than by producing inflation forecasts (Isard and Laxton, 2000). For example, they can be used to convey the authorities' views on the risks to the inflation forecast in an internally consistent fashion to external observers.

Small-scale models can help central banks think through policy transmission channels. More important, models can serve as a framework for policy discussion and can even assist in the presentation of the inflation forecasts that are essential to transparency. Fan charts, showing the probability distribution of inflation forecasts over a range of outcomes, are a recent improvement in presentation that is facilitated by quantitative models (Allen, 1999). 
Time series models impose less economic structure but may provide better short-term forecasts, as well as a consistency check for the larger structural models. Univariate models of the aggregate inflation index, components of the index, or other key inflation indicators are relatively easy to produce and allow for frequent assessment of economic conditions. In New Zealand, output from these models is used to help build forecasts for the first two quarters beyond the most recent historical data, while those for quarters further out tend to be governed more by the economic relationships embedded in large-scale models. Multivariate time series models (e.g., vector auto regression) allow for the simultaneous interaction between time series with few, if any, structural assumptions. Such models are also used by the central banks of Brazil, Chile, and Israel.

In practice, inflation forecasts are based on a combination of indicator variables, quantitative economic models, and qualitative information and judgment. Inflation targeting central banks typically first analyze the output from their economic models and other assorted inflation indicators, and then apply judgment based on qualitative information gathered from their contacts in all sectors of the economy to arrive at a view regarding the appropriate stance for monetary policy. 
Table A2. Monetary Policy Indicators in Inflation Targeting Countries

\begin{tabular}{|c|c|c|}
\hline \multirow[t]{2}{*}{$\begin{array}{l}\text { Aggregate Demand and } \\
\text { Supply }\end{array}$} & Aggregate Demand & $\begin{array}{l}\text { Consumption } \\
\text { Residential investment } \\
\text { Other investment and stock building } \\
\text { Public sector budgetary } \\
\text { Exports } \\
\text { Imports } \\
\text { Other main current account items }\end{array}$ \\
\hline & Aggregate Supply & $\begin{array}{l}\text { Output } \\
\text { Labor demand/(un) employment indicators } \\
\text { Wage growth } \\
\text { Profit margin } \\
\text { Productivity } \\
\text { Opinion/expectation surveys of any of the above } \\
\text { Index of some of the above (lcading indicators index) }\end{array}$ \\
\hline \multirow[t]{3}{*}{ Financial Sector Indicators } & Quantities & $\begin{array}{l}\text { Broader monetary aggregates } \\
\text { Credit aggregates }\end{array}$ \\
\hline & $\begin{array}{l}\text { Interest and Exchange } \\
\text { Rates }\end{array}$ & $\begin{array}{l}\text { Key market interest rates } \\
\text { Exchange rate } \\
\text { Monetary conditions index } \\
\text { Lending rate vs. market rate spread }\end{array}$ \\
\hline & $\begin{array}{l}\text { Interest and Exchange } \\
\text { Rate Expectations }\end{array}$ & $\begin{array}{l}\text { Term structure of interest rates } \\
\text { Info on interest rate expectations from forwards, futures, } \\
\text { options, and the like } \\
\text { Interest spread against key foreign rates } \\
\text { Info on exchange rate expectations from indexed debt, or } \\
\text { forwards, futures, options, and similar factors }\end{array}$ \\
\hline Inflation Expectations & & $\begin{array}{l}\text { Information derived from inflation-indexed debt } \\
\text { Central bank surveys of inflation expectations } \\
\text { Market forecasts of inflation }\end{array}$ \\
\hline Price indices & & $\begin{array}{l}\text { Derived CPI measures and sub-indices (underlying, median, } \\
\text { trimmed, and the like) } \\
\text { Wholesale prices/producer prices } \\
\text { Raw material/commodity prices } \\
\text { Import/export prices } \\
\text { Property prices } \\
\text { Equity prices and related derivative prices }\end{array}$ \\
\hline
\end{tabular}

Sources: Central bank websites. 


\section{REFERENCES}

Agénor, Pierre-Richard, C. John McDermott, and Eswar S. Prasad, 1999, "Macroeconomic Fluctuations in Developing Countries: Some Stylized Facts," IMF Working Paper 99/35 (Washington: International Monetary Fund).

Alexander, William E., and others, 1995, The Adoption of Indirect Instruments of Monetary Policy, IMF Occasional Paper No. 126 (Washington: International Monetary Fund).

Allen, William A., 1999, "Inflation Targeting: The British Experience," Bank of England Ilandbooks in Central Banking Lecture Series, No. 1 (London: Bank of England).

Armour, Jamie, and Agathe Côté, 2000, "Feedback Rules for Inflation Control: An Overview of Recent Literature," Bank of Canada Review (Winter 1999-2000), pp. 43-54.

Baliño, Tomás J.T., and Lorena M. Zamalloa, 1997, Instruments of Monetary Management. Issues and Country Experiences (Washington: International Monetary Fund).

Banco de Mexico, "A Strategy for Accumulating Reserves Through Options to Sell Dollars. The Case of Banco de Mexico," available on the web at (http://www.banxico.org.mx).

Bernanke, Ben S., Thomas Laubach, Frederic S. Mishkin, and Adam S. Posen, 1999, Inflation Targeting: Lessons from International Experience (Princeton, New Jersey, Princeton University Press).

Blejer, Mario I., Alain Ize, Alfredo M. Leone, and Sergio Werlang, eds., 2000, Inflation Targeting in Practice: Strategic and Operational Issues and Application to Emerging Market Economies (Washington: International Monetary Fund).

Blejer, Mario I., Alfredo M. Leone, Pau Rabanal, and Gerd Schwartz, 2001, "Inflation Targeting in the Context of IMF-Supported Adjustment Programs," IMF Working Paper 01/31 (Washington: International Monetary Fund).

Bogdanski, Joel, Tombini, Alexandre A., and Sérgio Ribeiro da Costa Werlang, 2000, "Implementing Inflation Targeting in Brazil," Banco Central do Brasil Working Paper No. 1 (Brasilia).

Borio, Claudio E.V., 1997, "The Implementation of Monetary Policy in Industrial Countries: A Survey," Bank for International Settlements Economics Paper No. 47 (Basel).

Chauvet, Marcelle, 2000, "Leading Indicators of Inflation for Brazil," Banco Central do Brasil, Working Paper No. 7 (Brasilia). 
Clinton, Kevin, 2000, "Strategic Choices for Inflation Targeting in the Czech Republic," in Inflation Targeting in Transition Economies: The Case of the Czech Republic, ed. by Warren Coats (Washington: International Monetary Fund).

— , and Mark Zelmer, 1997, "Constraints on the Conduct of Canadian Monetary Policy in the 1990s: Dealing with Uncertainty in Financial Markets," Bank of Canada Technical Report No. 80 (Ottawa: Bank of Canada).

Coats, Warren, ed., 2000, Inflation Targeting in Transition Economies: The Case of the Czech Republic (Washington: International Monetary Fund).

Cottarelli, Carlo, and Angeliki Kourelis, 1994, "Financial Structure, Bank Lending Rates, and the Transmission Mechanism of Monetary Policy," Staff Papers, International Monetary Fund, Vol. 41, No. 4, pp. 587-623.

Debelle, Guy, 1997, "Inflation Targeting in Practice," IMF Working Paper 97/35 (Washington: International Monetary Fund).

Drew, Aaron, and Benjamin Hunt, 1998, "The Forecasting and Policy System: Preparing Economic Projections," Reserve Bank of New Zealand Discussion Paper G98/7 (Wellington).

Folkerts-Landau, David, and Carl-Johan Lindgren, 1998, Toward a Framework for Financial Stability, IMF World Economic Financial Surveys (Washington: International Monetary Fund).

Haldane, Andrew, 2000, "Targeting Inflation: The U.K. in Retrospect," in Strategic and Operational Aspect of Inflation Targeting. International Experience and the Application to Emerging Economies, ed. by Mario I. Blejer, and others (Washington: International Monetary Fund).

Huang, Haizhou, and Shang-Jin Wei, 2001, "Corruption and Monetary Policy" (unpublished; Washington: International Monetary Fund).

Isard, Peter, and Douglas Laxton, 2000, "Inflation-Forecast Targeting and the Role of Macroeconomic Models," in Inflation Targeting in Transition Economies: The Case of the Czech Republic, ed. by Warren Coats (Washington: International Monetary Fund).

- , and Ann-Charlotte Eliasson, 2000, "Simple Monetary Rules Under Policy Uncertainty," in International Finance and Financial Crises: Essays in Honor of Robert P. Flood, Jr., ed. by Peter Isard, Assaf Razin, and Andrew K. Rose (Kluwer: Boston and Washington).

Landerretche, Oscar, Felipe Morandé, and Klaus Schmidt-Hebbel, 1999, "Inflation Targets and Stabilization in Chile," in Central Bank of Chile Working Paper No. 55 (Santiago). 
Laxton, Douglas, and Alasdair Scott, 2000, "On Developing a Structured Forecasting and Policy Analysis System Designed to Support Inflation-Forecast Targeting (IFT)," paper presented at the Inflation Targeting Conference held at the Central Bank of the Republic of Turkey, Ankara, October 19-20, 2000.

Leiderman, Leonardo, and Hadas Bar-Or, 2000, "Monetary Policy Rules and Transmission Mechanisms Under Inflation Targeting in Israel," Research Department, Bank of Israel (Jerusalem).

Leiderman, Leonardo, and Gil Bufman, 2000, "Inflation Targeting Under a Crawling Band. Exchange Rate Regime: Lessons from Israel," in Strategic and Operational Aspects of Inflation Targeting. International Experience and the Applications to Emerging Economies, ed. by Mario I. Blejer, and others (Washington: International Monetary Fund).

Leone, Alfredo M., 1999, "Inflation Targeting in the Brazilian Setting," in Brazil: Selected Issues and Statistical Appendix, IMF Country Staff Report No. 99/97 (Washington: International Monetary Fund).

Malo de Molina, José Luis, José Viñals and Fernando Gutiérrez, 1998, "Monetary Policy and Inflation in Spain," Saint Martin's Press.

Masson, Paul R., Miguel A. Savastano, and Senil Sharma, 1997, "The Scope for Inflation Targeting in Developing Countries," IMF Working Paper 97/130 (Washington: International Monetary Fund).

Mehran, Hassanali, Bernard Laurens, and Marc Quintyn, 1996, Interest Rate Liberalization and Money Market Development: Selected Country Experiences (Washington: International Monetary Fund).

Mishkin, Frederic S., 2000, "Inflation Targeting in Emerging Market Countries," National Bureau of Economic Research Working Paper No. 7618 (March).

- and Klaus Schmidt-Hebbel, 2001, "One Decade of Inflation Targeting in the World: What Do We Know and What Do We Need to Know?" National Bureau of Economic Research Working Paper No. 8397 (July).

Price, Robert T., 1997, "The Rationale and Design of Inflation-Indexed Bonds," IMF Working Paper 97/12 (Washington: International Monetary Fund).

Schaechter, Andrea, Mark R. Stone, and Mark Zelmer, 2000, Adopting Inflation Targeting: Practical Issues for Emerging Market Countries, IMF Occasional Paper No. 202 (Washington: International Monetary Fund). 
Sherwin, Murray, 2000, "Strategic Choices in Inflation Targeting: The New Zealand Experience" in Inflation Targeting in Practice: Strategic and Operational Issues and Application to Emerging Market Economies, ed. by Mario I. Blejer, and others (Washington: International Monetary Fund).

Söderlind, Paul, and Lars E. O. Svensson, 1997, "New Techniques to Extract Market Expectations from Financial Instruments," NBR Working Paper No. 5877 (Cambridge, Massachusetts: National Bureau of Economic Research).

Sundararajan, V., Peter Dattels, and Hans J. Blommestein, eds., 1997, Coordinating Public Debt and Monetary Management (Washington: International Monetary Fund).

Svensson, Lars E. O., 1997, "Inflation Forecast Targeting: Implementing and Monitoring Inflation Targets," European Economic Review, Vol. 41, pp. 1111-1146.

Taylor, John B., ed., 1999, Monetary Policy Rules, (Chicago: University of Chicago Press).

Van't dack, Joseph, 1999, "Monetary Policy Operating Procedures in Emerging Market Economies," Bank for International Settlements Policy Paper No. 5 (Basel).

White, William R., 1999, "Evolving International Financial Markets: Some Implications for Central Banks," Bank for International Settlements Working Paper No. 66 (April) (Basel).

World Bank and International Monetary Fund, 2001, Developing Government Bond Markets: $A$ Handbook (Washington). 